\title{
Simulation supported business process performance assessment
}

\author{
Rajala, M. M. \\ Neste Oy \\ P.O.Box 20 \\ FIN-02151 Espoo \\ phone +358-20 450 4725, fax +358-204504352 \\ Email Mikko.Rajala@neste.com
}

\begin{abstract}
Information integration, process integration or even the synergy between these two do not have their own intrinsic value. How they are experienced by the customer and how they serve the company adds to their significance. When building an integration framework or when rethinking business processes the value to the customers should be the guiding factor and the performance should be assessed from this viewpoint. In practice this is however difficult with the current modelling approaches being rather more structure than value oriented.
\end{abstract}

This paper presents a new way to combine existing familiar methods from different disciplines to achieve the customer orientation in rethinking business processes. The combination of methods also helps to identify the shared set of parameters in the business processes to respond to changes in an effective, timely and process-wide coherent manner. Combined methods support the cognitive process of human beings, where knowledge on enterprise, constraints of operating environment and goals of modelling are synthesised to produce new design alternatives. On the other hand, the approach takes advantage of computer simulation showing the real world potential hidden in different design alternatives. The methods are tested in a real world case of InterNAPS Ltd. in the process of handling key document-type (the Documentary Credit) information in the network of delivery logistics.

\section{Key words}

Business process, design, integration, value analysis, assessment, variation, simulation. 


\section{INTRODUCTION}

Attaining better business process performance raises many questions concerning the means for performance planning. In order to design and maintain superior performance it is substantive to know the constraints of an existing process and its operation environment. The company has to identify internal and external discontinuities, customer and stakeholder requirements for understanding the operation environment (Collins et al., 1991). It is essential to reconcile the outcome of current business processes to fit external requirements, market situation including competitors and internal capabilities. In practice this leads to a modelling task in which the behavioural properties of the current process and its future alternatives are studied (MacArthur et al., 1994).

Enterprise models are produced through a cognitive process (see Figure 1), where knowledge on enterprise, constraints of operating environment and goals of modelling are synthesised to produce new design alternatives (Smith and Browne, 1993). Due to diverse design goals different model representations may be used to provide aid for design decision making. In this paper a new strategy for business process performance assessment is introduced. The strategy is suited for a form of design approach, which uses value analysis (Miles, 1972) for design processes, failure mode and effects analysis (FMEA) to point out weaknesses of the current process (MIL-STD-1629A, 1980), and computer simulation to measure the operation of new design alternatives. The approach to value analysis was basically designed for product development but has since been extended to functional cost analysis (Yoshikawa et al., 1994) and business process re-engineering (Rajala and Savolainen, 1995). Equally, FMEA was originally developed for reliability engineering (Soin, 1992) nowadays being extended to failure mode analysis of business processes (Rajala, 1995).

The design strategy can be put in a five step procedure:

1) Identify the goals and constraints of enterprise task environment.

2) Develop model representations for the current business process.

3) Determine performance characteristics of the current process.

4) Generate model alternatives for the current process.

5) Evaluate different models through simulation supported value analysis and select solutions for further development and implementation. 


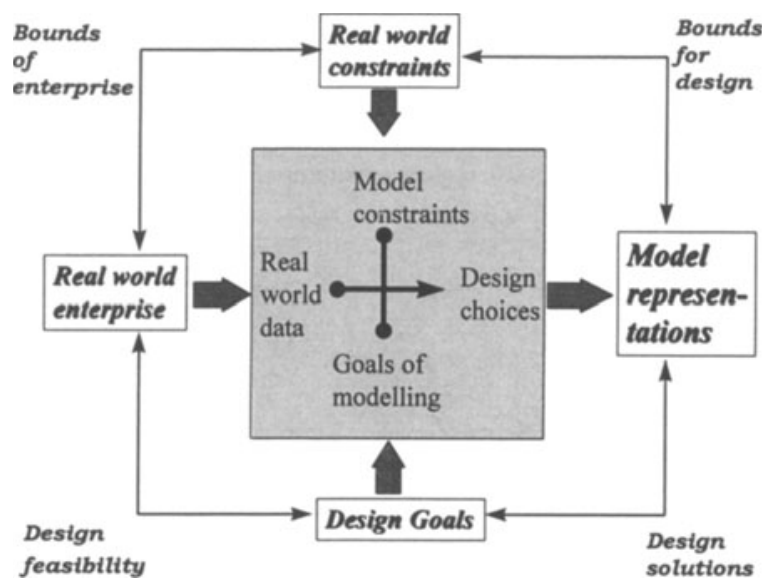

Figure 1 Design process in a constrained environment.

The relevance of the new approach to business process design is shown through a case of InterNAPS Ltd, which is a joint venture company owned by Finnish Neste Corporation and Russian InterTechnology Ltd. producing solar panel components for solar energy systems. This paper shows, by using the listed design principles, how familiar methods for product planning can be used in designing business processes, and how computer simulation can be used in assessing different design alternatives in a real world case.

\section{SIMULATION SUPPORTED BUSINESS PROCESS PERFORMANCE ASSESSMENT- A REAL WORLD CASE}

\subsection{Goals and constraints of enterprise task environment}

Neste Advanced Power Systems (NAPS), engaged in the development and global marketing of solar and wind power systems, has production facilities and operations in many countries, for example Finland, France, Russia, and Thailand. InterNAPS Ltd., a joint venture operating in Russia, produces crystalline silicon photovoltaic components for solar panels. Components are either sold to third part companies or assembled into solar electricity panels by NAPSSolartron Manufacturing Thailand Ltd (NSMT).

In Figure 2 an extract from InterNAPS enterprise model is presented. The business process called "Sales management" is described using hierarchical IDEF0- model (FIPSPUB 183, 1993). The "Sales management"-process of InterNAPS consists of six subprocesses: A1: "Make offers" , A2: "Agree on trade terms" and A3:"Enter order", A4:"Confirm order", "A5:"Make the Documentary Credit", A5:"Transfer order for processing". In the first subprocess an offer is made to a customer and in the second more precise trade terms are determined. In the third and fourth subprocesses the customer's order is accepted and 
confirmed, respectively, and in the fifth the terms of documentary credit and payment are determined. The sixth subprocess takes care of transferring the order for delivery logistics.

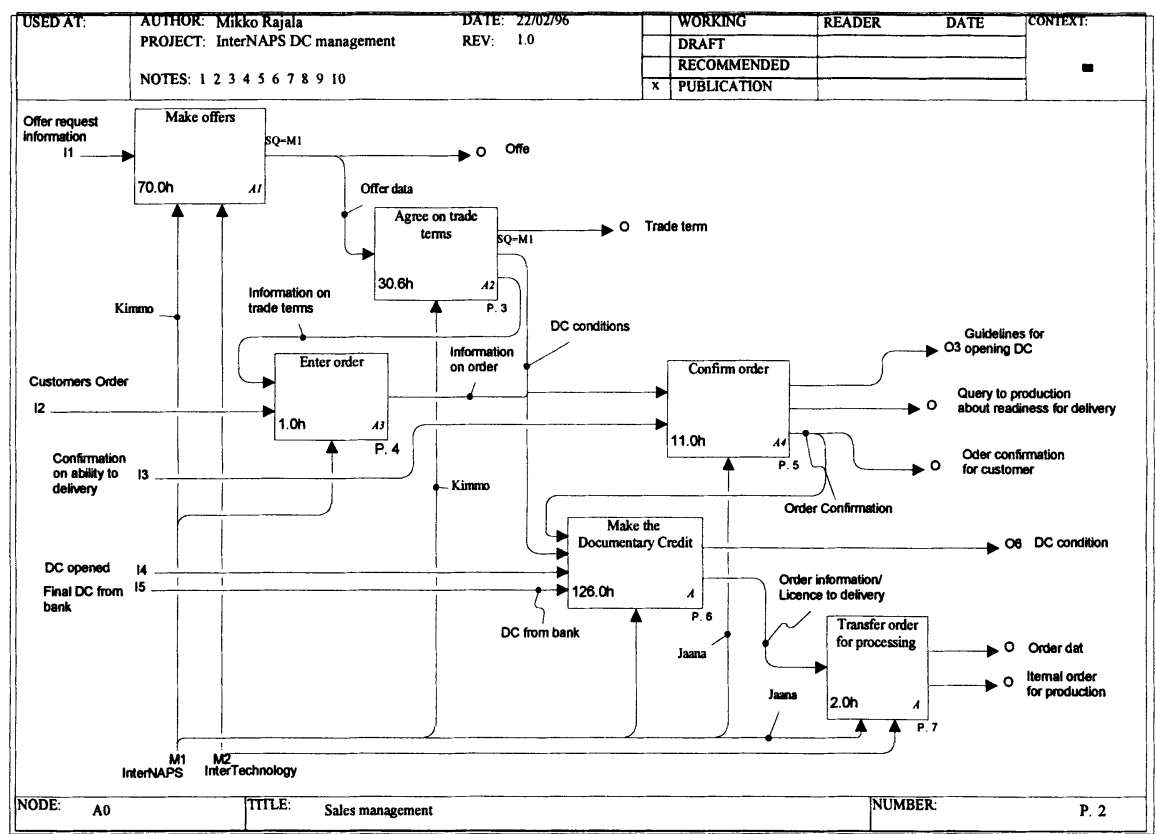

Figure 2 Main functions of InterNAPS "Sales management" process.

The InterNAPS sales process is dependent on international agreements (ICC, 1993) concerning Documentary Credit (DC) trade, primarily ruled by banks and financial institutions. These agreements include many constraints to be taken into account. InterNAPS has to follow the agreements making the redesign work even more challenging. The business, based on use of Documentary Credit in practise, means that customer and supplier have to make contract according to certain formats. The banks (both customers and suppliers) are responsible for all details in the contract specified in the regulations. Customers redeem the products from customs of destination port using DC-documents. Special attention is paid to document names, written in accordance to the DC-document.

The document based trading causes many practical problems to the sales function of InterNAPS Ltd. These problems were processed by using documented Failure Modes and Effects Analysis worksheets (see Table 1). The basic problem in "Make the Documentary Credit", as concluded from Table 1, is the duration of DC handling process performed by banks, InterNAPS and the customer. The length is mainly due to banks, but a remarkable amount of time and money is also wasted in correcting DC documents. This is partly caused by international DC regulations requiring that every detail in DC, for example document names or weights of packages, are written in exactly the same way as in corresponding shipping documents. An associated problem is the variation of time needed to perform the 
DC handling. Both problems cause difficulties in scheduling of delivery logistics (see Table 1). The customer register difficulties as delayed deliveries. Therefore, ability to control the time for the DC-making is important.

The objective of redesign was to make "Sales management" more efficient in terms of time and money. It means keeping the order processing under better control by minimising the variation of processing time and costs, and to reduce the negative effects on manufacturing scheduling.

Table 1 An extract from Failure Modes and Effects analysis

\begin{tabular}{|c|c|c|c|c|c|}
\hline & Failure mode & Cause & Effect & Effect Amount & Corrective action \\
\hline$\overline{1}$ & $\begin{array}{l}\text { Handling process } \\
\text { takes too long } \\
\text { with the banks }\end{array}$ & $\begin{array}{l}\text { Banks want to } \\
\text { make money }\end{array}$ & $\begin{array}{l}\text { Cash flow planning gets } \\
\text { difficult, production get } \\
\text { problems due to lack of } \\
\text { cash }\end{array}$ & $\begin{array}{l}\text { Time delay 1-3 } \\
\text { weeks }\end{array}$ & $\begin{array}{l}\text { Follow principle "Do it right } \\
\text { at once". Make clear } \\
\text { guidelines for defining the } \\
\text { terms of DC }\end{array}$ \\
\hline 2 & $\begin{array}{l}\text { There is a need } \\
\text { for close } \\
\text { correction with } \\
\text { every DC }\end{array}$ & $\begin{array}{l}\text { Documents not } \\
\text { written correctly }\end{array}$ & $\begin{array}{l}\text { Extra costs due to } \\
\text { changes, allocation of } \\
\text { delivery logistics is } \\
\text { difficult }\end{array}$ & $\begin{array}{l}\text { Costs } \\
(100-1000 \$)\end{array}$ & $\begin{array}{l}\text { Ready filled model created } \\
\text { considering documentary } \\
\text { credit }\end{array}$ \\
\hline
\end{tabular}

\subsection{Performing Value Analysis (VA) to generate new designs for performance assessment}

On the basis of analysed behaviour of process network (see Table 1) the decision was made to select a subprocess starting from "Enter order" as an object for redesign studies. As recalled "Enter order" takes in the customer's order. The order is passed on to "Confirm order". "Make the Documentary Credit" takes care of the correct terms of Documentary Credit. Finally, "Transfer order for Processing" puts orders into a process ending with product shipment. The DC- management is, as noted above, a process in the extended enterprise environment containing time spending subprocesses performed by banks and the customer.

\section{Determination of functional roles of process activities}

The first step of VA is to define activities of the main functions and, as well, to define which the supporting functions are. From a process chain perspective it is obvious that "Enter order" and "Make the documentary credit" are the main activities most important for a successful deal with the customer (Table 2). "Confirm order" and "Transfer order for processing" are supporting activities. Focusing the redesign work essentially on "Make the Documentary Credit" is thus suggested, because the "Enter Order" is a rather straightforward subprocess and does not need any redesign effort. 
Determination of the objective for process redesign via functional cost analysis The suggestion to focus on "Make the Documentary Credit" also arises from the functional costs analysis performed parallel with average lead time analysis. According to Table 3, the process of Documentary Credit management ("Make the Documentary Credit") causes the biggest expenses also being a subprocess with a long lead time. The goal of process redesign is now to develop such a process where DCs, with corresponding paper management, are done in a quicker and less costly way.

Table 2 Functional analysis: process chain view.

\begin{tabular}{lllll}
\hline Reference & Action & Object & Main function & $\begin{array}{l}\text { Supporting } \\
\text { function }\end{array}$ \\
\hline A3 & Enter & order & $\mathrm{x}$ & $\mathrm{x}$ \\
A4 & Confirm & order & & \\
A5 & Make & the documentary credit & $\mathrm{x}$ & $\mathrm{x}$ \\
A6 & Transfer & order for processing & & \\
\hline
\end{tabular}

Table 3 Functional costs -analysis incorporated with average lead time analysis

\begin{tabular}{|c|c|c|c|c|c|c|}
\hline $\begin{array}{l}\text { Hours } \\
\text { spent in } \\
\text { the } \\
\text { activity } \\
\text { (h) }\end{array}$ & $\begin{array}{l}\text { Cost due } \\
\text { to } \\
\text { activity } \\
\text { (Cost } \\
\text { units) }\end{array}$ & $\begin{array}{l}\text { Order } \\
\text { management } \\
\text { (\% of costs) }\end{array}$ & $\begin{array}{l}\text { Make the } \\
D C(\% \text { of } \\
\text { costs) }\end{array}$ & $\begin{array}{l}\text { Order } \\
\text { management } \\
\text { (\% of time) }\end{array}$ & $\begin{array}{l}\text { Make the } \\
\text { DC (\% of } \\
\text { time) }\end{array}$ & \\
\hline 38 & 670 & 91.3 & & 86.4 & & Agree on trade terms \\
\hline 2 & 20 & 2.7 & & 4.5 & & Enter order \\
\hline 4 & 44 & 6.0 & & 9.1 & & Confirm order \\
\hline 35 & 335 & & 21.3 & & 23.3 & $\begin{array}{l}\text { Negotiate on terms of } \\
D C\end{array}$ \\
\hline 4 & 45 & & 2.9 & & 2.7 & $\begin{array}{l}\text { Study contents of } D C \\
\text { initiative }\end{array}$ \\
\hline 25 & 260 & & 16.5 & & 16.7 & $F \ddot{x} D C$ \\
\hline 25 & 272 & & 17.3 & & 16.7 & Accept DC \\
\hline 28 & 291 & & 18.5 & & 18.7 & $\begin{array}{l}\text { Inspect DC received } \\
\text { from bank }\end{array}$ \\
\hline 32 & 360 & & 22.8 & & 21.3 & $\begin{array}{l}\text { Compare DC with } \\
\text { order confirmation }\end{array}$ \\
\hline 1 & 13 & & 0.8 & & 0.7 & Permit delivery \\
\hline
\end{tabular}




\section{Generating design alternatives for current business process}

During an idea generation session (IDEGEN++, 1995), the design team generated ideas of which two were selected to solve the problems connected to current process.

The first idea is to develop standard sheets and a database for DC and order handling, and then introduce these to customers, manufacturing units and transportation units. The idea is supposed to prevent the errors due to writing and is expected to shorten the processing time due to failures. The effect of this idea on process topology is that no heavy checking and rewriting for DC-documents is needed. Final cross checking with order confirmation can be skipped because all the documents and forms are stored in the database.

The second idea is to end negotiations on DC terms with customer before taking banks in to the process. The idea is supposed to shorten the processing time spent in banks due to elimination of extra processing iterations. The effect on process topology is that heavy rewriting of DC can be eliminated.

\subsection{Evaluation of different models through simulation}

The selected design alternatives were evaluated using computer simulation via the ServiceModel-package of ProModel Corporation (ServiceModel, 1995). Design techniques were used in the simulation experiment to plan the simulation runs. In these runs a warm-up period was used before the actual simulation. In the model it was supposed that personnel was able to handle either one (1) or three (3) parallel processes at the same time. The frequency of arriving orders was distributed either according to normal distributions $N(35 \mathrm{~h}, 7$ h) or $\mathrm{N}(70 \mathrm{~h}, 9 \mathrm{~h})$ and the corresponding number of arriving orders was either 10 or 30.

The simulation results of new designs were then compared to performance of the current process. Each model was evaluated by calculating relative performance profile $(G a l e, 1994)$ in respect to the present process (Table 4).

It can be seen from Table 4 that saved average time of system performance is remarkable in both cases. Performance increases about $53 \%$ for model design alternative one and $50 \%$ for model design alternative two (refer to Table 4 and Figure 3). Correspondingly, costs due to time spent on processing decreases about $67 \%$ in design case one and $54 \%$ in design case two. 
Table 4 Design ideas with evaluation results obtained through simulation

\begin{tabular}{|c|c|c|c|c|}
\hline Idea & $\begin{array}{l}\text { Effect of idea on } \\
\text { system performance } \\
\text { if realised }\end{array}$ & $\begin{array}{l}\text { Effect of idea } \\
\text { on process } \\
\text { topology if } \\
\text { realised }\end{array}$ & $\begin{array}{l}\text { Average timed } \\
\text { effect on system } \\
\text { performance } \\
\text { (simulated) }\end{array}$ & $\begin{array}{l}\text { Average cost } \\
\text { effect on system } \\
\text { (simulated) }\end{array}$ \\
\hline $\begin{array}{l}\text { 1. Develop standard } \\
\text { sheets and a data } \\
\text { base for } \\
\text { Documentary } \\
\text { credit and order } \\
\text { confirmation, } \\
\text { introduce these to } \\
\text { customers, } \\
\text { manufacturing } \\
\text { units and } \\
\text { transportation } \\
\text { units. }\end{array}$ & $\begin{array}{l}\text { Prevent failures due } \\
\text { to writing, shortens } \\
\text { the processing time } \\
\text { due to failures. } \\
\text { Makes it easier to } \\
\text { allocate delivery } \\
\text { logistics }\end{array}$ & $\begin{array}{l}\text { No heavy } \\
\text { checking and } \\
\text { rewriting for } \\
\text { DC-documents } \\
\text { needed. Final } \\
\text { cross checking } \\
\text { with order } \\
\text { confirmation } \\
\text { can be skipped. }\end{array}$ & $-53 \pm 26 \%$ & $-67 \pm 9 \%$ \\
\hline $\begin{array}{l}\text { 2. End negotiations } \\
\text { on terms of } \\
\text { Documentary } \\
\text { credit with the } \\
\text { customer before } \\
\text { taking banks in to } \\
\text { the handling } \\
\text { process }\end{array}$ & $\begin{array}{l}\text { Shorten the } \\
\text { processing time spent } \\
\text { in banks. Eliminate at } \\
\text { least one iteration in } \\
\text { processing. Makes it } \\
\text { easier to allocate } \\
\text { delivery logistics. }\end{array}$ & $\begin{array}{l}\text { No heavy } \\
\text { rewriting of } \\
\text { DC needed. }\end{array}$ & $-50 \pm 22 \%$ & $-54 \pm 16 \%$ \\
\hline
\end{tabular}
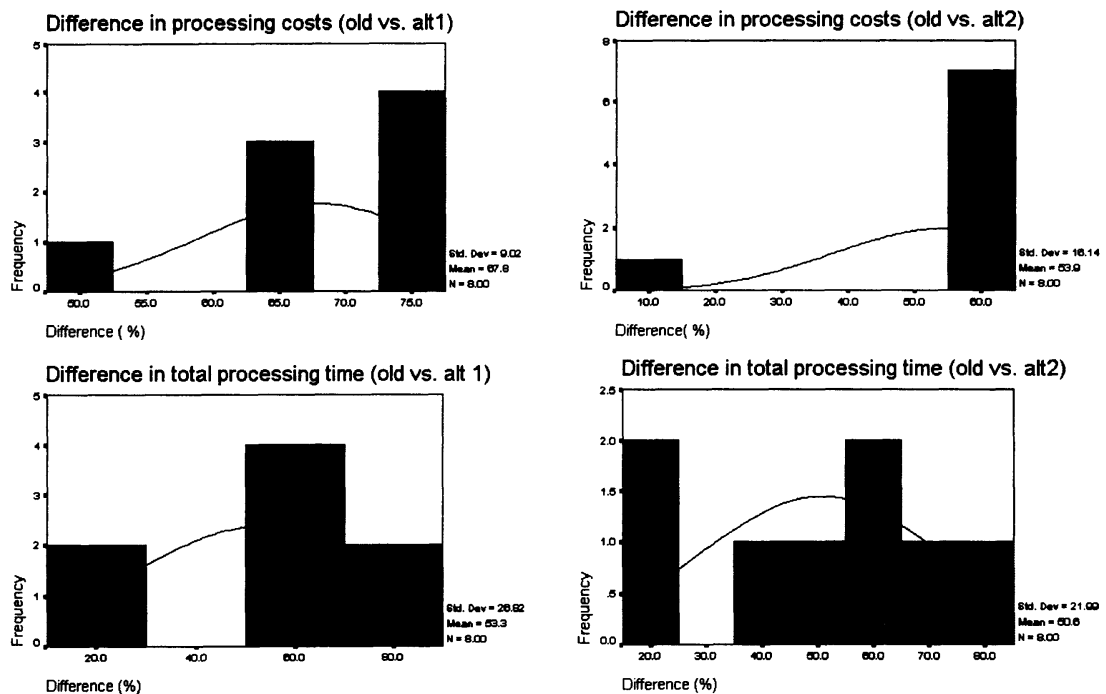

Figure 3 Differences in costs and processing time (\%) 


\subsection{Suggested new solution and its consequences to delivery logistics}

As a consequence to suggested changes in "Sales management"- process, the lead time of order processing was supposed to be reduced significantly (50-53\%). The simulation results also indicate that the costs due DC-management would decrease effectively (54-67\%). Furthermore, the variation of costs, total time and working time spent in order processing was supposed to be lowered.

The above mentioned effects were obtained after implementation of the design alternative one, but not occurring in full scale as indicated by simulation. However, an additional but not minor benefit was perceived, namely due to smaller variation in lead times of order processing and DC-management the scheduling of manufacturing and logistics was easier to perform. The main result from the redesign and assessment effort was the ability of InterNAPS to more timely deliveries giving more value for customers.

\section{CONCLUSIONS}

A performance assessment procedure for business process designs is presented and applied to a real world case at InterNAPS Ltd. The procedure is based on co-use of human cognitive process supported by conceptual principles of design problem solving and computerised simulation techniques. When setting up the methodology, it was found that the human design process can be speeded up and design decision making confirmed by intellectual use of simulation. The foundation forms a ground of a strategy for computerised business process design. The strategy and the procedure are especially helpful in evaluating the differences between various versions of business process systems of extended enterprise. The other strengths of the proposed strategy are:

1) The approach connects human design processing with computerised evaluation of produced models.

2) Produced information can be effectively used in comparative performance analysis via modified VA.

3) Managerial decision quality is improved due to the consistency and objectivity of presented approach.

4) Simulation balances the inconsistencies caused by human judgement.

Process simulation through defined methodology arises important questions concerning methods to improve the efficiency of operations performed in the extended enterprise. The proposed design strategy reduces complexity of enterprise design problem by providing an analytical tool for decision making. With such tools more intelligent decisions on current and future enterprise systems can be made. 


\section{REFERENCES}

Browne, J., Sackett, P. J. and Wortmann, J. C. (1995) Future manufacturing systems- Towards the extended enterprise, Computers in Industry, 25, 235-254.

Collins R. S., Oliff, M. D. and Vollman, T. E. (1991), Manufacturing Restructuring: Lessons for Management. Manufacturing 2000: Executive Report Series, Executive Report Number 2, International Institute for Management Development, Lausanne, Switzerland, August.

FIPS Publication 183, (1993) Integration Definition for Function Modelling (IDEF0), Computer Systems Laboratory, National Institute of Standards and Technology, Gaithersburg, Md 20899, USA.

Gale, B. T. (1994) Managing Customer Value: Creating quality and service that customer can see. The Free Press, New York.

Hoover S. V. and Perry, R. F. (1989) Simulation: A Problem-Solving Approach, AddisonWesley, Reading, Massachusetts.

ICC Uniform Customs and Practise for Documentary Credits, (1993) International Chamber of Commerce, The world business organisation, ICC Publishing SA, Paris, France.

IDEGEN++ idea generation software and manual. CAC-Research Oy, Finland, P.O. Box 10, 02361 Espoo, 1990-1995.

Jensen, K. (1990) Coloured Petri Nets: A High level language to system design and analysis. In G. Rozenberg (eds.): Advances in Petri Nets, Lecture Notes in Computer Science, Springer-Verlag.

MacArthur, P. J., Crosslin, R. L. and Warren, J. R. (1994) A Strategy for Evaluating Alternative Information Systems Designs for Business Process Reengineering, International Journal of Information Management, 237-251.

Miles, L.D. (1972) Techniques of Value Analysis and Engineering, 2. edition, McGraw-Hill Book Company, New York.

Procedures for Performing a Failure Modes, Effects and Criticality Analysis, United States Military Standard MIL-STD-1629A (1980).

Rajala, M. (1995) Exploration methods for business process simulation modelling, Pre-prints of "CIM at Work - Co-operation in Manufacturing" conference, Eindhoven University of Technology, Holland.

Rajala, M. and Savolainen, T. (1995) Value analysis in business process re-engineering, Preprints of "CIM at Work - Co-operation in Manufacturing" conference, Eindhoven University of Technology, Holland.

ServiceModel User's Guide (1995), version 2.0, ProModel Corporation, USA

Smith, G. F. and Browne, G. J. (1993) Conceptual Foundations of Design Problem Solving. IEEE Transactions on Systems, Man and Cybernetics, 23, September/October 1993.

Soin, S. S. (1992) Total Quality Control Essentials - Key elements, Methodologies, and Managing for Success, McGraw-Hill, New York.

Viswanadham, N. and Narahari, Y. (1992) Performance Modelling of Automated Manufacturing Systems, Prentice-Hall, Englewood Cliffs, New Jersey. 
Yoshikawa T., Innes J. and Mitchell F. (1994) Applying functional cost analysis in a manufacturing environment. Int. $J$ Production Economics 36, 53-64.

\section{BIOGRAPHY}

Mr Mikko Rajala is currently working as a manager responsible for business process modelling at Neste Oil's Information Systems Management in Espoo, Finland. Neste is a multidivisional company producing oil products, gas energy and solar power energy systems, and specialised chemicals for different applications. Mr Rajala has since 1987 acted as an research mathematician and since 1994 until 1996 as a enterprise modelling consultant for Neste's business units. In his work he has also participated in different European working groups working on engine test methods to be used within CEC (Co-ordinating European Council for the Development of Performance Tests for Transportation Fuels, Lubricants and other Fluids). Mr Rajala received his MSc degree in 1985 and the Licentiate of philosophy (for $\mathrm{PhD}$ ) degree in 1991 in Applied Mathematics from the University of Helsinki. $\mathrm{Mr}$ Rajala is currently finishing his studies for Doctoral degree in Industrial Economics at the Helsinki University of Technology. 